\title{
全球定位系统测定的尼泊尔 $M_{\mathrm{w}} \mathbf{7 . 8}$ 级地震 同震位移
}

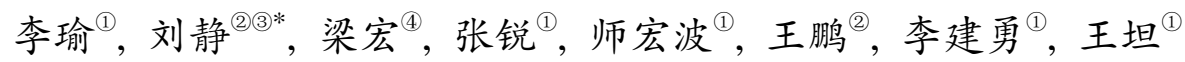

(1) 地壳运动监测工程研究中心, 北京 100045 ;

(2) 中国地震局地质研究所, 地震动力学国家重点实验室, 北京 100029;

(3) 中国科学院青藏高原研究所, 北京 100101;

(4) 中国气象局气象探测中心, 北京 100081

* 联系人, E-mail: liu-zeng @ies.ac.cn

2015-08-17 收稿, 2015-09-30 接受, 2015-11-30 网络版发表

地震科技星火计划(XH15056Y)、中国地震局地震行业专项(201208006, 201308012)和国家杰出青年科学基金(41225010)资助

摘要 据尼泊尔境内的连续GPS观测资料显示, 2015 年 4 月 25 日的尼泊尔 $M_{\mathrm{w}} 7.8$ 级地震造成 尼泊尔向南移动, 最大位移量达到了 $1.88 \mathrm{~m}$. 利用国家重大科技基础设施项目“中国大陆 构造环境监测网络”、中国气象局中日合作JICA项目及加州理工学院在尼泊尔境内所建的 连续GPS观测资料, 分析了此次地震对中国大陆构造形变场的震时动态响应及同震影响. 结果显示, 地震造成中国西藏地区毫米至厘米级的同震水平位移, 最大值在震中北东方 向, 震中距 $220 \mathrm{~km}$ 的珠峰站, 约为 $30 \mathrm{~mm}$, 波及范围远至 $1500 \mathrm{~km}$ 之外的高原东北部的祁 连山地区. $1 \mathrm{~Hz}$ 的高频 GPS数据分析表明, 震中距 $1200 \mathrm{~km}$ 内的站点记录了弹性震波和永 久变形的叠加和破裂方向效应等丰富信息. 通过分析中国境内地震活动频度并对比 2011 年日本宫城地震发现, 本次尼泊尔地震并未造成中国境内微震活动显著增加, 同震过程 对中国西藏部分地区、川滇地区及南北地震带断裂带的应力扰动和构造加载有限, 与其震 级相对较小有关.

2015 年 4 月 25 日 14 时 11 分 26 秒 (06 时 11 分 26 秒 $\mathrm{UTC})$, 尼泊尔 $\left(28.247^{\circ} \mathrm{N}, 84.708^{\circ} \mathrm{E}\right)$ 发生了矩震级 $\left(M_{\mathrm{w}}\right) 7.8$ 级地震 (http://earthquake.usgs.gov/earthquakes/ eventpage/us20002926\#general_summary), 震中位于 加德满都西北约 $80 \mathrm{~km}$, 距离尼泊尔第二大城市、著 名的旅游胜地波克拉较近, 震源深度 $15 \mathrm{~km}$. 地震释 放的能量与 2008 年 5.12 汶川 $M_{\mathrm{w}} 7.9$ 级地震相当. 据尼 泊尔内政部统计, 截至 2015 年 5 月 10 日, 累计发生余 震 150 余次, 地震至少造成 8019 人死亡, 17866 人受伤, 中国西藏、印度、孟加拉国、不丹等地均出现人员伤 亡. 而且, 地震还造成当地山体滑坡及雪崩, 雪崩波
及范围远至中国珠峰地区.

\section{1 地质构造背景}

青藏高原是中国现代最新构造活动与地震活动 最强烈的地区 ${ }^{[1]}$. 青藏高原南缘的喜马拉雅构造带是 印度板块与欧亚板块的俯冲、碰撞边界, 这一过程开 始发生于距今55 65 Ma, 至今仍处于强烈推挤过程 中 $^{[2 \sim 7]}$. 喜马拉雅构造带由主中央逆冲断裂 $(\mathrm{MCT})$ 、主 边界逆冲断裂 (MBT) 和主前锋逆冲断裂 (MFT) 三大断 裂系组成, 在深部3条断裂都交汇于低倾角的喜马拉 雅主逆冲断裂 ${ }^{[8]}(\mathrm{MHT})$. 从主中央逆冲断裂, 到主边 
界逆冲断裂, 再到主前锋逆冲断裂, 活动性依次向南 发展, 即起始时间逐渐变新. 且MBT和MFT晚第四 纪以来仍在活动 ${ }^{[9]}$, 尤其是其南部最新活动边界的 MFT活动性最强, 位于尼泊尔地区的南北向地壳缩 短速率为 $21 \pm 1.5 \mathrm{~mm} / \mathrm{a}^{[8]}$.

喜马拉雅构造带是一条强烈活动带, 沿着长达 $2500 \mathrm{~km}$ 的喜马拉雅构造带在已知历史上发生过至少 8 次 $M_{\mathrm{w}} 7.5$ 级以上大地震, 从西到东分别为 2005 年 Kashmir $M_{\mathrm{w}}$ 7.6地震, 1905 年Kangra $M_{\mathrm{w}} \sim 7.8$ 级地震, 1803 年 $M_{\mathrm{w}} \sim 7.5$ 级地震, 1505 年中尼泊尔 $M_{\mathrm{w}} \sim 8.2$ 级地 震，1934年Bihar-Nepal $M_{\mathrm{w}} \sim 8.1$ 地震，1950年察隅
$M_{\mathrm{w}} \sim 8.4$ 级地震和 1897 年西陇高原 $M_{\mathrm{w}} \sim 8.1$ 级地震 ${ }^{[10]}$. 同时, Bilham等人 ${ }^{[11]}$ 和Ader等人 ${ }^{[12]}$ 对历史上印度板 块周边强震破裂的空间分布进行了研究, 可以发现 此次地震恰恰发生 1505 年 $M_{\mathrm{w}} 8.2$ 级地震和 1934 年 $M_{\mathrm{w}} 8.1$ 级地震破裂区域之间，与 1833 年地震破裂区可 能有重合(图1).

\section{2 已有研究结果}

地震发生后，多家研究机构给出的此次地震的 震源机制解表明，这次地震属于典型的喜马拉雅型 (即低角度逆断层型)强震，发震断层可能是深部的主

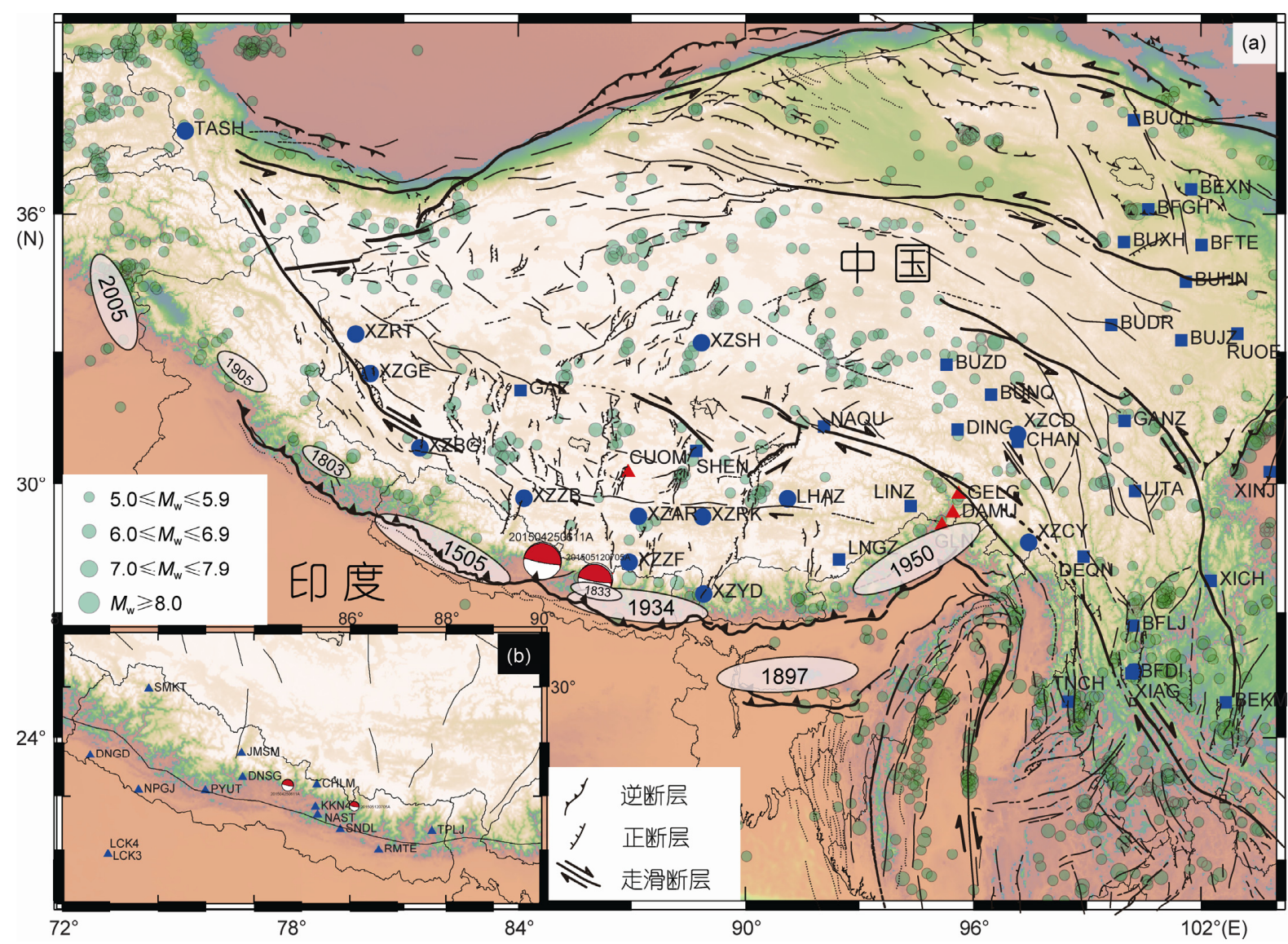

图 1 区域地质构造图及 GPS 点位分布图. 红白沙滩球分别表示尼泊尔 $4.25 M_{\mathrm{w}} 7.8$ 级地震和 $5.12 M_{\mathrm{w}} 7.3$ 级地震的震中位置, 震源机制解为 GCMT 结果(http://www.globalcmt.org/); (a) 蓝色圆点为中国大陆构造环境监测网络 GPS 站点, 蓝色方形点为中国气象局中日合作 JICA 项目 GPS 站点, 红色三角点为中国地震局地质研究所建 GPS 站点; (b) 蓝色三角点为加州理工学院和剑桥大学所建 GPS 站点. 绿色圆点表示历史地 震, 历史地震目录来源于中国地震台网中心地震数据管理与服务系统(http://www.csndmc.ac.cn), 数据起止时间为 1970-01-01 2014-12-31; 断 层引自 Tapponnier ${ }^{[13]}$; 椭圆阴影区域标示对应地震的大致破裂区域 ${ }^{[11,12]}$

Figure 1 Map of active faults, historical earthquakes, topography, and locations of GPS stations. Red-White beach balls represent epicenter locations of the April $25 M_{\mathrm{w}} 7.8$ and May $12 M_{\mathrm{w}} 7.3$ earthquakes in Nepal, The focal mechanisms are based on the published results by the global centroid moment tensor project (GCMT, http://www.globalcmt.org); (a) blue dots denote the CMONOC's stations, blues squares for JICA, CMA stations, red triangles for IGCEA stations, respectively; (b) Caltech and Cambridge's GPS stations are shown by blue triangles; green dots show historical earthquakes in this area from January 1, 1970 to December 31, 2014, downloaded from the CSNDMC, CENC website (http://www.csndmc.ac.cn); active faults are modified from Tapponnier et al. ${ }^{[13]}$; shaded ellipses mark rupture areas of the corresponding large historical earthquakes in the Himalaya ${ }^{[11,12]}$ 
喜马拉雅逆断层MHT, 发震断层走向 $295^{\circ}$, 向北倾 斜 $11^{\circ}$, 释放地震矩 $6.623 \times 10^{20} \mathrm{Nm}$, 对应矩震级 $M_{\mathrm{w}} 7.8$ (http://earthquake.usgs.gov/earthquakes/eventpage/ us20002926\#scientific_tensor:us_us_20002926_mww). 地震波反演结果表明, 发震断层面上破裂主要分布 于初始破裂点东侧区域, 而后向 $115^{\circ}$ 方向扩展, 属 于单侧破裂. 断层面上平均滑动约 $3 \mathrm{~m}$, 最大滑动量 可达 $5 \mathrm{~m}$, 滑动极值区 (asperity) 在地表的投影位于震 中和加德满都盆地之间(http://www.gsi.go.jp/cais/topic150429-index-e.html). 余震分布在震中以东的区域, 南北向投影 $\sim 0 \mathrm{~km}$, 东西向 160 km(USGS, http:// earthquake.usgs.gov), 大致与破裂范围相对应, 且多 数散布在主震位移极值区的外围.

ARIA研究团队在震后快速分析了尼泊尔境内的 连续GPS观测数据, 给出了尼泊尔境内的同震位移场 (http://aria-share.jpl.nasa.gov/events/20150425-Nepal_EQ/ GPS/20150425 Nepal_ARIA_Final_Offsets_v4.txt). 结 果显示, 尼泊尔中部地区存在明显的南向位移, 水平 位移在加德满都东部地区达到极大, 约为 $1.88 \mathrm{~m}$, 同 时这一地区还存在近 $1.26 \mathrm{~m}$ 的抬升, 同时在加德满都 北部靠近西藏地区也存在 $0.6 \mathrm{~m}$ 左右的沉降. 根据同 震GPS位移场资料, 结合InSAR资料及远场地震波资 料联合反演断层破裂分布, 初步结果发现最大滑移 $\sim 6 \mathrm{~m}^{[14]}$ (http://aria-share.jpl.nasa.gov/events/20150425Nepal_EQ/Fault_and_Deformation_Models/ARIA_Gorkha_ Fault_Model.jpg). 这一结果略大于仅用地震波反演 得出的滑移量. 除去反演中参数设置和约束条件的 选取可能造成反演结果存在差异之外, 联合反演中 加人的近场 GPS 同震数据及InSAR数据也大大提高 了对破裂断层浅部的分辨能力. 考虑到此次地震是 一次低倾角的逆冲型地震, 断层绝对滑动量与破裂 面积之间的耦合关系较一般地震更为严重 ${ }^{[15]}$, 单一 数据仅能提供震源过程较差的部分图像, 而多数据 联合反演可以给出稳健的震源破裂图像 ${ }^{[16]}$. 此外, 由于所用到的震后 InSAR数据大多是震后 $10 \mathrm{~d}$ 左右 的, 对于大地震来说, 不排除由此所获得的同震位移 场中包含有部分震后余滑的成分.

虽然, ARIA研究团队给出了此次地震的GPS同 震位移场, 但由于缺乏中国大陆内部的资料, 仅局限 于尼泊尔境内, 造成其对此次地震给喜马拉雅地区 造成的影响认识不完整, 尤其是对中国大陆内部西 藏地区. 而且, 由尼泊尔境内的GPS台站资料获得的
是尼泊尔地震近-中场同震位移, 远场同震位移是如 何分布的? 其影响范围有多大? 中国西藏地区在地 震后先后发生的定日 5.9 级地震和聂拉木 5.3 级地震和 此次地震有何关系? 上述问题的回答不仅有助于认 识此次地震的发震构造与破裂空间分布, 对于了解 其对中国西藏地区以及川滇地区地震危险性的影响 也至关重要.

\section{3 观测数据概况}

\section{1 中国境内观测数据}

中国境内的GPS站点共计 48 个, 主要包含三部 分, 分别是中国大陆构造环境监测网络(以下简称“陆 态网络”)的连续GPS基准站14个、中国气象局中日合 作 JICA 项目的连续 GPS 基准站 28 个、IGS站点 2 个 (LHAZ和HYDE(印度)) 以及中国地震局地质研究所 项目所建连续GPS台站4个. 台站分布图见图1所示.

\section{2 尼泊尔境内观测数据}

尼泊尔境内的GPS站点是尼泊尔地质矿产部 (Department of Mines and Geology of Nepal)和加州理 工学院(California Institute of Technology)共同合作建 设、运行和维护, 全境共建有 29 个GPS连续站点, 由 于此次地震的影响及震前震后数据的缺失, 本文中 共计使用14个站点 ${ }^{[17]}$, 台站分布图见图1.

\section{4 数据分析与结果}

首先利用GAMIT/GLOBK软件 ${ }^{[18,19]}$ 提供的TRACK 模块对震后快速获取的震中距 $1300 \mathrm{~km}$ 范围的陆态网 络站点 $1 \mathrm{~Hz}$ 的GPS数据进行处理, 获得了震时中国西 藏南部地区地表形变过程(图2). 本文处理的各站点 1 $\mathrm{Hz}$ 数据的时段起止时间为 $06: 10: 00 \sim 06: 20: 00$ (UTC 时间), 卫星星历采用 IGS精密星历, 以 L1 和 L 2 的线 性组合 LC 为观测量消除电离层一阶项的折射影响, 采用GPT2模型改正对流层的天顶延迟 ${ }^{[20]}$, 映射函数 采用GMF模型 ${ }^{[21]}$. 计算时, 考虑到TRACK模块采用 相对定位方法，处理基线不易过长，选取的参考站点 要稳定且观测精度较高, 且震时不受或受地震影响 较小, 不存在明显的地表位移. 经对同震结果进行显 著性检验分析, 表明此次尼泊尔 $M_{\mathrm{w}} 7.8$ 级的同震影响 集中在震中距 $600 \mathrm{~km}$ 范围内, 故本文选取震中距约 为 $695 \mathrm{~km}$ 的西藏双湖 $(\mathrm{XZSH})$ 站作为参考站. 为了削 

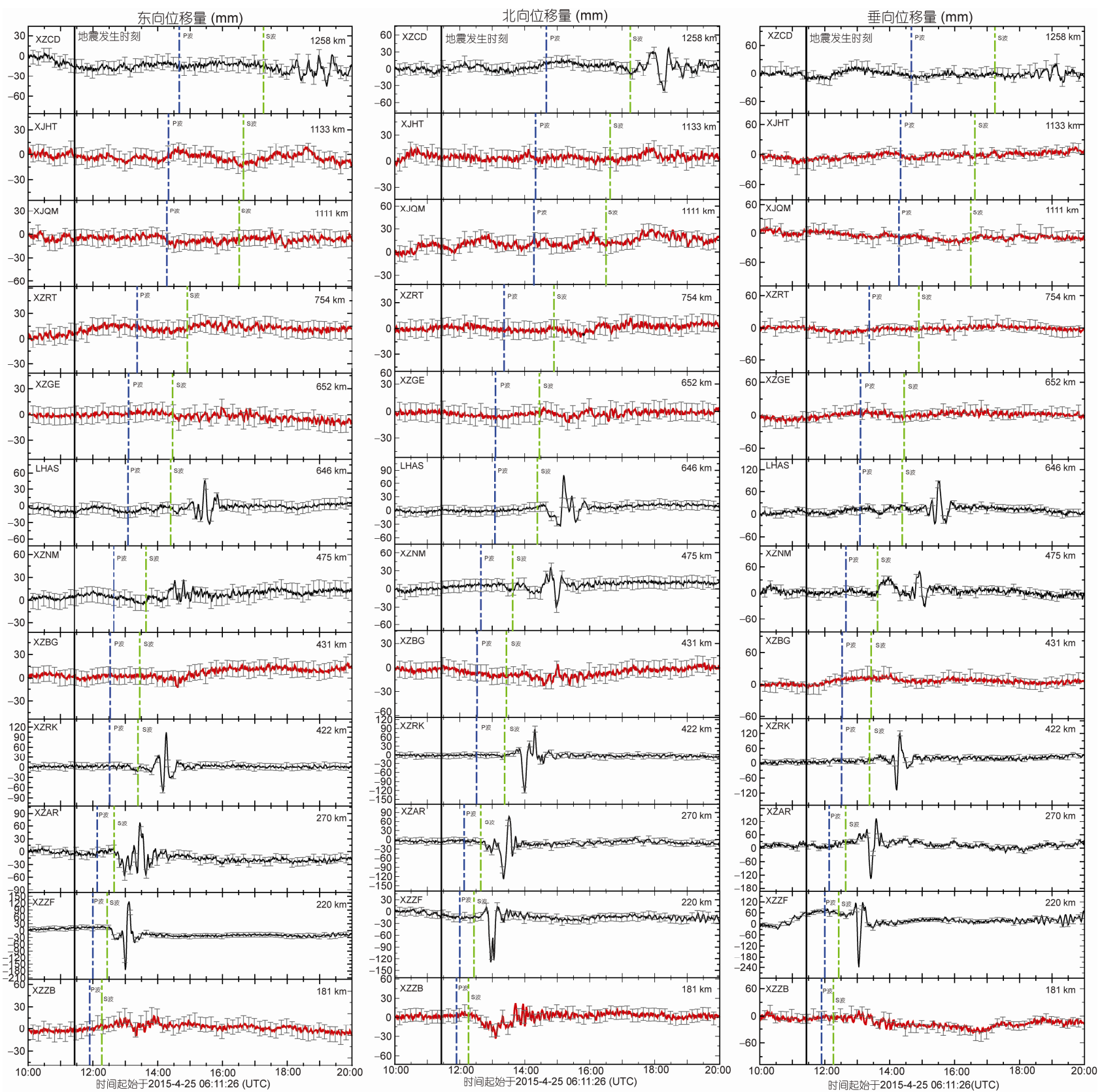

图 2 部分中国 GPS 站点记录的三方向地震图. 横坐标表示时间(单位: min), 实线表示位于震中东侧(黑色实线)和西侧(红色实线)站点记录的 地震图, 右上角数字表示站点震中距, 黑色坚实线表示地震发生时刻, 坚虚线表示利用 TAUP 软件以标准模型计算得到 P 波(蓝色虚线)和 S 波 (绿色虚线)到达各站点时刻(http://ds.iris.edu/ds/nodes/dmc/software/downloads/taup/)

Figure 2 Examples of Chinese high-rate GPS station recording of seismic waveforms in the north-south, east-west, and vertical directions. The $x$-axis represents time (unit: min); solid lines show seismic waveforms recorded at sites located in the east (black) and west (red) of the epicenter; numbers in the upper right corner are epicentral distances in kilometers; black vertical solid lines indicate start time of earthquake; vertical dashed lines represent the $\mathrm{P}$ (blue) and S (green) wave arrival times computed using TAUP and based on the standard model (http://ds.iris.edu/ds/nodes/dmc/software/downloads/taup/)

除站点重复性误差(多路径误差)等, 本文利用震前 2 $\mathrm{d}$ 的数据, 采用改进的恒星日滤波方法 ${ }^{[22]}(\mathrm{MSF})$ 对结 果进行了修正, 具体做法不再详述. 在进行完 MSF 后, 还会有一些有色噪声误差残留, 并在小范围内呈
现一定的系统性，即某种时空相关的误差，共模误 差. 考虑到文中涉及站点分布较广, 故采用分区域进 行堆栈滤波(Stacking)方法提取站点的共模误差并予 以剔除 ${ }^{[23,24]}$. 结果显示, 震中距 $1200 \mathrm{~km}$ 内的台站均 
有不同程度的震动, 震动大小与震中距、台站地下地 质构造及台站相对于震源破裂传播方向的方位相关, 特别是后者. 比如, 位于震中北东东 $220 \mathrm{~km}$ 的西藏珠 峰站 $(X Z Z F)$ 的振幅远大于震中北西 $181 \mathrm{~km}$ 的西藏仲 巴站 $(X Z Z B)$, 虽然后者的震中距更小. 随着震中距 的逐渐变大, 各站点震时响应的振幅大小依次减小, 并震中两侧相同震中距的站点有很大差异(西藏噶尔 站(XZGE)和西藏拉萨站(LHAS)、西藏巴嘎站(XZBG) 和西藏日喀则站 $(X Z R K))$. 震时东西向最大形变量达 到约 $280 \mathrm{~mm}$, 南北约 $150 \mathrm{~mm}(X Z Z F)$, 且震中以东地 区形变量明显大于震中以西地区, 这与此次地震是 向东单侧破裂结果一致. 从各站点对地震响应的时 间上来看, 可以直观地感受到地震波由震中向外传播 的过程, 在此过程中, 各站点的运动轨迹不尽相同.

随后, 利用 GAMIT/GLOBK 软件 ${ }^{[18,19]}$ 处理了 2015年4月20 27日全球近 140 个IGS台站、国内近 50 个西藏及周边的连续GPS台站以及尼泊尔境内的 14 个连续GPS台站的观测数据. 但尼泊尔境内的GPS台 站震后只采用 4 月 25 日一天的观测数据, 且研究区域 内(尼泊尔、西藏及周边) 所有台站 4 月 25 日的观测数 据只采用UTC 06:30 24:00时间段(地震发生于4月 25 日 UTC $06: 11: 19$ ). 采用震前 $5 \mathrm{~d}$ 左右的数据是为 了弥补在地震前后更短时间内部分站点数据缺失或 数据质量欠佳的影响, 而震后尼泊尔境内的站点只 使用震后 $1 \mathrm{~d}$ 的数据, 是由于尼泊尔境内靠近震中附 近的站点震后滑移显著, 且发生过较大余震. 联合处 理全球IGS台站的数据确保参考框架的统一和自洽, 保证了同震位移的可靠性 ${ }^{[25]}$.

获得的同震位移场结果如图3和表 S1所示. 由此 可以看出此次地震在中国西藏南部地区产生了明显 的同震水平位移. 最大位移发生在西藏珠峰站(XZZF) 附近, 达30 mm, 方向南西南. 珠峰站北侧的昂仁站 (XZAR)也产生了 $23 \mathrm{~mm}$ 的同震水平位移, 方向与珠 峰站一致. 而距离震中最近的西藏仲巴站 $(X Z Z B$, 约 $182 \mathrm{~km})$, 则产生了 $17 \mathrm{~mm}$ 的同震水平位移, 方向南 东南, 考虑可能与此次地震单侧东向破裂有关. 中国 青海西南部、云南西部地区也监测到了毫米级位移 2 6 mm, 整体方向南西. 尼泊尔境内连续GPS台站 的同震位移矢量与ARIA研究团队给出的结果基本吻 合 (图 4). 最大同震水平位移发生在 KKN4站, 达 $\sim 1889 \mathrm{~mm}$, 方向近正南, 而且伴有 $1267 \mathrm{~mm}$ 的上升. 位于震中近正北面的CHLM站也存在 $1408 \mathrm{~mm}$ 的水
平位移, 方向近正南, 但其存在 $587 \mathrm{~mm}$ 的沉降, 与 ARIA研究团队给出的InSAR结果 (http://aria-share. jpl.nasa.gov/events/20150425-Nepal_EQ/Interferogram/ ARIA_Coseismic_ALOS2_interferogram_PathA157_20150221_0502_1_5m.jpg)对比, 上升与沉降区域基本 吻合. 震中东西两侧站点RMTE和DNSG站点分别向 东西两侧运动, 呈现挤出运动状态. 整体图像遵从弹 性半空间逆冲破裂造成的位移场分布特征. 将地震 造成的同震位移场以震中开始, 分别向北北东方向 和南东东方向(地震破裂方向)做剖面(图5), 结果显 示此次尼泊尔地震同震的影响集中在震中周围 600 $\mathrm{km}$ 范围内, 且两个方向大致呈现指数衰减, 南东东 方向同震效应影响距离与地震破裂长度有很好的对 应关系. 地震造成的垂向位移在中国境内很微弱, GPS的定位精度暂时还检测不到.

针对此次尼泊尔 $M_{\mathrm{w}} 7.8$ 级地震的震源破裂过程反 演, 尼泊尔境内的高频GPS数据(http://aria-share.jpl. nasa.gov/events/20150425-Nepal_EQ/GPS/High-Rate_ Position_Time_Series)发挥了重要作用 ${ }^{[14,17]}$. 相比之 下，中国西藏境内的高频GPS数据因距离4月 25 日尼 泊尔主震破裂区较远，在约束主震同震破裂中提供 的信息和重要性要弱于尼泊尔境内的站点. 但是, 考 虑到中国西藏地区目前整体地震台网较稀疏, 对地 震的监测能力较弱, 并且与传统地震仪相比, GPS记 录也没有地震仪的振幅限制, 速度或加速度积分经 常出错、噪声放大和扭曲真实信号等局限, 因此GPS 能够有效监测大幅度的地面震动, 特别是在大地震 的近场区成为地震仪的重要补充, 为强震研究提供 了一种新的途径. 尤其, 2008 年 5 月 12 日汶川 $M_{\mathrm{w}} 7.9$ 级 地震是我国首次大范围将震时高频GPS数据应用于 地震研究中, 促进了我国GPS地震学的发展 ${ }^{[26,27]}$. 近 年来, 随着中国国家级GPS网络一中国大陆构造环 境监测网络 (以下简称“陆态网络”)的建成并运行, GPS 观测精度及处理方法的不断改进与提高, 高频(1 $\mathrm{Hz}$ )和超高频(20 50 Hz)GPS技术在强震研究领域得 到了越来越广泛的关注 ${ }^{[28]}$.

尼泊尔地震破裂的快速反演结果表明, GPS和 InSAR等地表形变数据提供重要约束. 比如, ARIA团 队利用GPS, InSAR和远场地震波资料的联合反演断 层破裂得到的最大滑移 $6 \mathrm{~m}$, 大于仅用地震波反演 得出的滑移量. 对于低倾角的逆冲型破裂, 远场震波 反演的不确定性，如位移滑动量值与破裂区大小的 


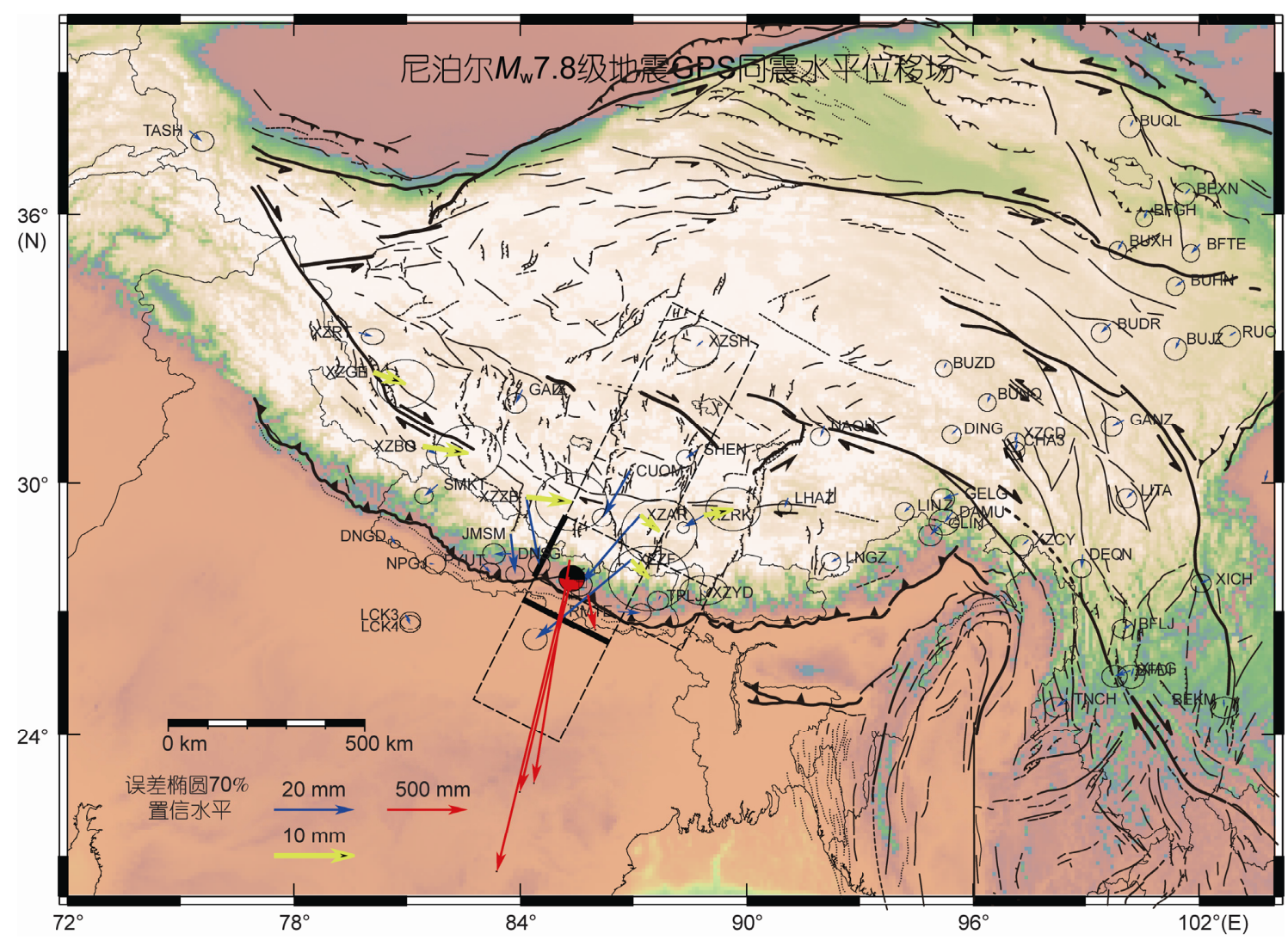

图 3 GPS 观测到的尼泊尔 $M_{\mathrm{w}} 7.8$ 级地震在中国西藏及周边地区产生的同震水平位移. 红色矢量箭头表示位于震中附近尼泊尔境内 4 个站点 的同震水平位移; 蓝色矢量箭头表示中国境内及尼泊尔境内部分站点的同震水平位移; 黄黑矢量箭头表示中国境内部分站点震后 $15 \mathrm{~d}$ 的水平 位移，误差椭圆置信水平 70\%; 黑色虚线框为剖面区域，黑色粗实线为剖面参考起始位置

Figure 3 Co-seismic horizontal displacement field of the $M_{\mathrm{w}} 7.8$ Nepal earthquake recorded by GPS stations in Tibet and the surrounding region. Red arrows show the displacements at four sites near the mainshock epicenter; blue arrows show displacements at various sites in China and Nepal; yellow-black arrows show displacements during $15 \mathrm{~d}$ after the mainshock at several sites in China, the error ellipses represent the $70 \%$ confidence level; black dashed rectangles denote the area of two profiles, with black solid lines starting positions of the profiles

权衡，位移空间分布是相对于震源而非绝对位置等, 对结果可信度的影响更大. 因此GPS等近中场地表 形变数据提供了不可或缺的数据约束.

截至目前，尼泊尔地震的同震破裂模型反映都 是基于远场地震波数据、InSAR数据和/或尼泊尔境内 的GPS同震位移数据. 这些破裂模型在没有中国境 内同震位移数据的约束下是否能够达到足够的精准 度存在疑问. 而且, 目前所有数据基本均位于喜马拉 雅构造带南侧, 北侧中国境内数据缺失严重, 这可能 会造成反演结果的系统性偏差. 因此，中国境内的同 震位移数据对此次地震破裂模型的精化提供了有益 的帮助.

\section{5 尼泊尔地震对中国地区的影响}

尼泊尔地震后, 仅 $10 \mathrm{~d}$ 内发生百余次余震, 其中
包括主震 $30 \mathrm{~min}$ 后的 $M_{\mathrm{s}} 7.0$ 级强余震，及其定结-定日 之间触发的正断层型小震群. $17 \mathrm{~d}$ 后, 于 5 月 12 日再次 发生 $M_{\mathrm{s}} 7.5$ 级地震, 位于主震北东方向, 靠近中国的 樟木口岸. 因此, 针对此次地震是否会对中国西藏及 川滇地区, 乃至南北地震带产生影响有较大的意见 分歧. 前人研究表明, 欧亚地震带内的印度板块北边 界地区的地震活动与中国大陆地震高潮期具有同步 性, 印度板块北边界的地震频次和活动水平的高值

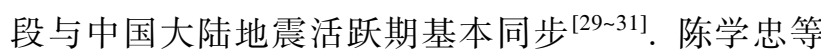
人 $^{[32]}$ 统计分析了 1900 年以来欧亚地震带年地震能量 比与中国大陆内发生 $M \geqslant 7$ 级地震的关系, 认为当欧 亚地震带年地震能力比高于 $50 \%$ 时，其后3年内中国 大陆地区将发生多次 7 级以上地震, 甚至有发生 8 级 地震的可能. 为此, 本文就此次地震后中国大陆整体 及川滇藏地区地震活动性进行了简要地分析. 

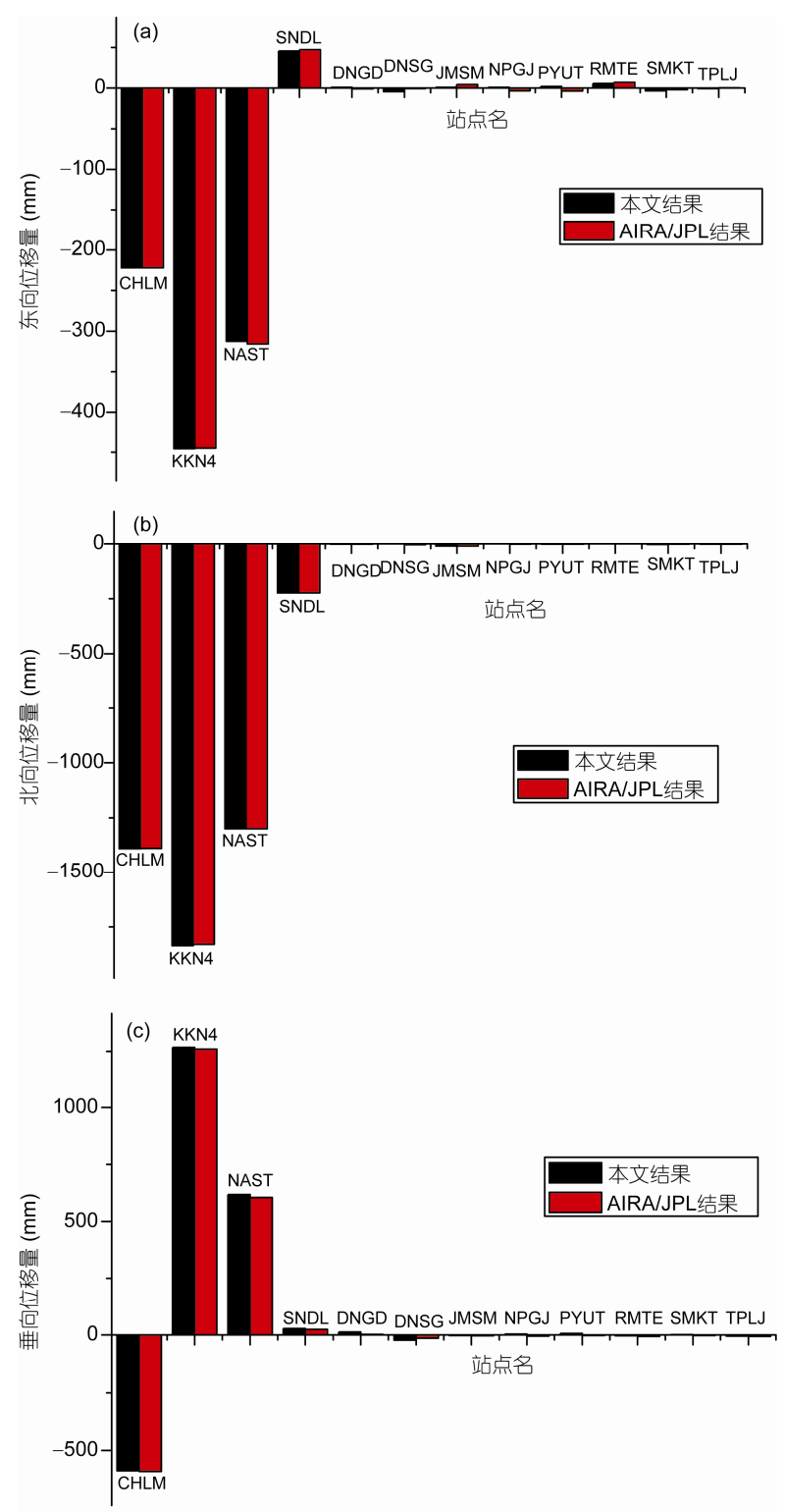

图 4 尼泊尔境内站点计算结果三方向对比图. (a) 东西向, (b) 南北 向, (c) 垂向

Figure 4 Comparison of co-seismic displacements at the stations in Nepal calculated in this paper and that by JPL/ARIA. (a) East-west, (b) north-south and (c) vertical

利用中国地震台网提供的统一地震目录, 对 2014-01-01 2015-05-18的中国大陆内部 $M_{\mathrm{s}} \geqslant 0$. 级的 地震活动频度(图6)进行了统计分析, 结果显示4月 25 日尼泊尔地震发生后3周内中国大陆及川滇藏地区整 体并没有出现更频繁的微震活动, 这一现象与 2011 年日本宫城大地震震后中国东北和华北地区微震活 动并未增加一致 ${ }^{[25]}$. 考虑可能原因是震级较该地区 历史大震较小, 且与地震破裂的方向、以及距离前一

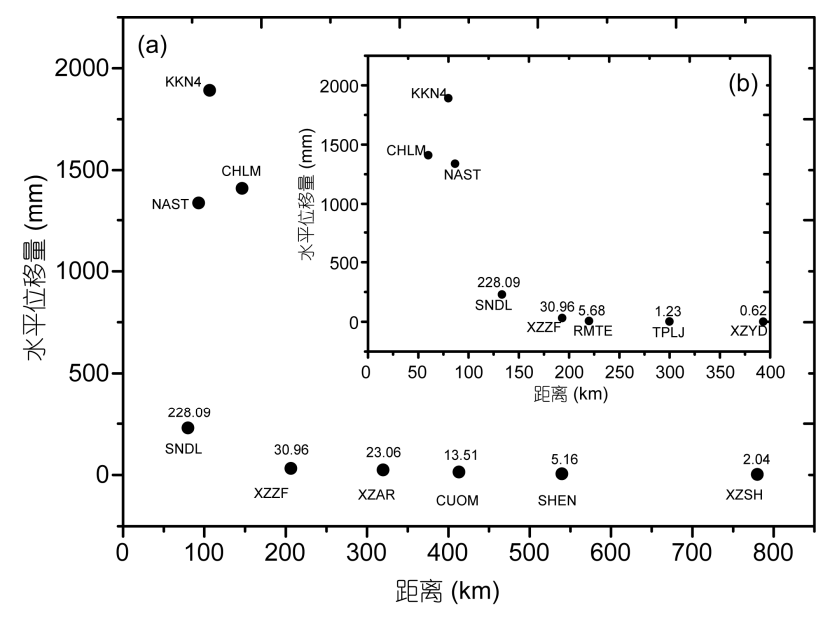

图 5 同震水平位移剖面图. (a) 北北东方向剖面图, (b) 南东东方向 剖面图. 剖面位置见图 3 虚线框

Figure 5 Profiles showing the variation in co-seismic horizontal displacement. (a) NNE and (b) SEE. Profile locations shown in Figure 3

次大震的间隔等因素有关 ${ }^{[33]}$. 基于尼泊尔地震同震 位移和青藏高原不同地区的优势断裂几何形态的库 伦应力分析也发现应力加载主要集中在与地震相邻 地区的西藏南部南北向正断层和近东西向右旋走滑 断裂上有接近或大于断裂应力触发的國值. 其触发 作用直观体现在主震 $3 \mathrm{~h}$ 后定日-定结之间震群小地 震 $\left(M_{\mathrm{s}} 2 \sim 5.7\right)$ 发生的重要因素. 从震中位置和震源机 制来看, 发震断层可能是发生在卡达正断层, 是申扎一 定结正断裂带的一支 ${ }^{[34]}$. 但对中国其他地区的断裂 上应力影响更小 ${ }^{[35,36]}$.

此外，利用中国境内 6 个震源区站点震后 $15 \mathrm{~d}$ 的 数据, 计算得到地震造成震后位移, 结果显示震后 GPS站点仍有南向运动趋势, 最大位移发生在XZZB 站, 达 5.6 mm. 然而, 由于该地区印度板块以 50 $\mathrm{mm} / \mathrm{a}$ 的速度向欧亚板块运动 ${ }^{[37]}$, 故站点东向位移由 西向东逐渐减小, 南向运动量由南向北逐渐减小, 但 整体上是同震效应的一个延续. 同时根据ARIA研究 团队利用震后 2 个星期的GPS观测数据所得出的此次 尼泊尔地震震后位移(http://aria-share.jpl.nasa.gov/ events/20150425-Nepal_EQ/GPS/20150512ARIA_Nepal_Postseismic_Map.pdf), 结果显示震后最大位移发 生在CHLM站, 达 17 mm, 且震后位移与同震位移 的方向也有较好的一致性. 因此, 在未来几年我们将 充分利用陆态网络等项目所建的GPS连续观测站资 料研究尼泊尔地震造成的中国西藏地区及川滇地区 应力应变场的演化, 从而深人理解区域内断裂带构 

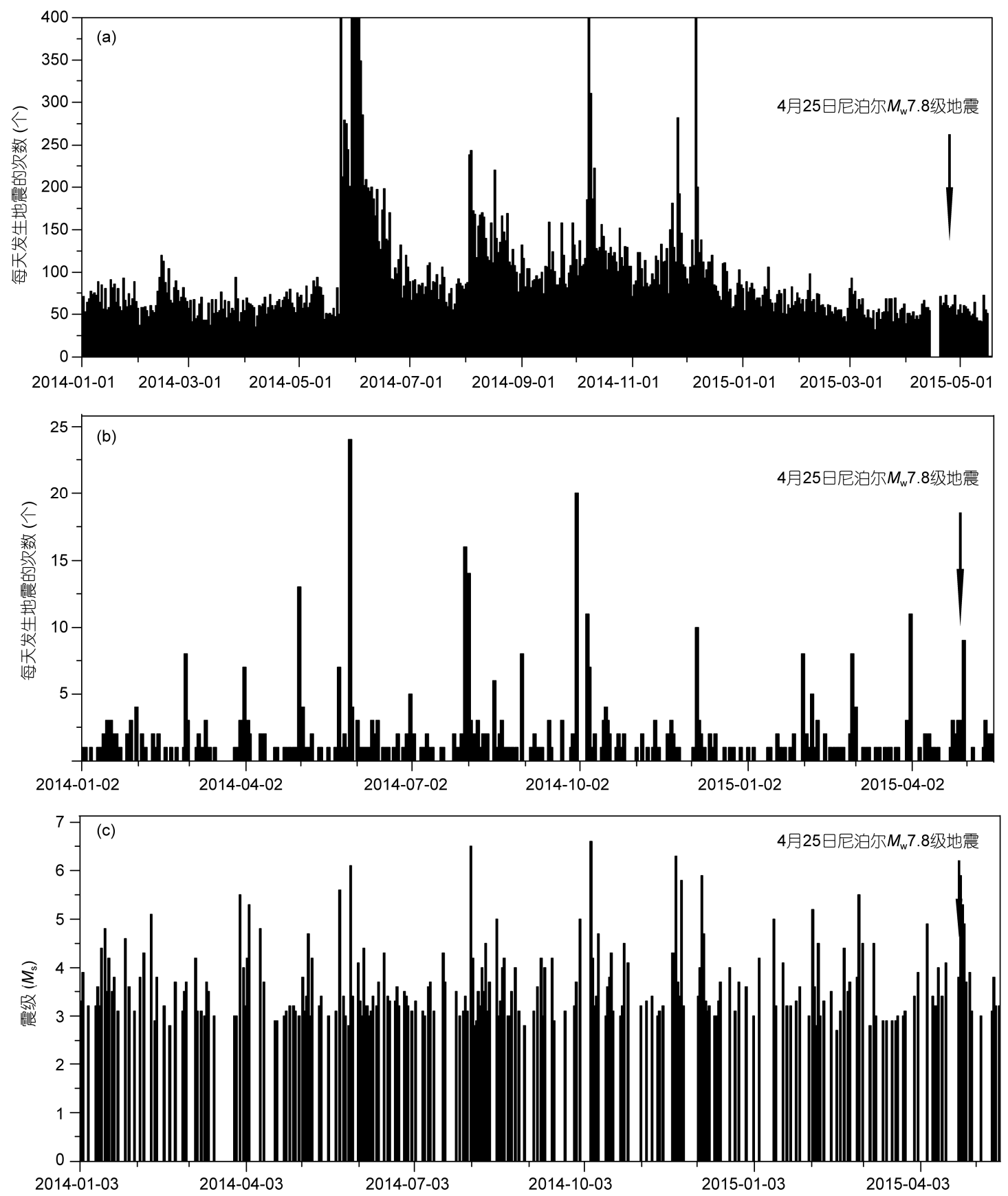

图 6 尼泊尔 $M_{\mathrm{w}} 7.8$ 级地震前后中国大陆(a)及川滇藏地区(b)地震活动频度图和 $M-t$ 图(c)

Figure 6 Number of daily earthquake occurrence in (a) mainland and (b) Sichuan, Yunan and Xizang region, and (c) $M-t$ plot of earthquakes in China, before and after the $M_{\mathrm{w}} 7.8$ Nepal earthquake

造加载的进程和地震危险性的变化, 为该地区的防 震减灾工作提供参考依据.

尼泊尔地震发生后，利用陆态网络的GPS观测 资料了解了此次地震所造成的地壳运动状态的变化, 同时也为认识地震的破裂过程提供了重要基础数据. 相比于流动的、不定期的GPS观测, 连续GPS观测能
够更快捷、更精确地获取地震所造成的同震位移场和 震后形变场及其时空演化过程．在西藏南部近震区 附近所新建的 13 个连续GPS 观测站, 这些站点的建 成和运行，必将极大地提升对这一地区地壳形变的 监测能力, 使洞悉此次地震形变场演化及震后效应 的全过程成为可能. 
致谢本文所使用尼泊尔境内的GPS数据由加州理工学院和剑桥大学Jean-Philippe Avouac教授提供; 中国境内GPS站 点数据由陆态网络项目、中国气象局中日合作JICA项目及中国地震局地质研究所提供; 文中图件利用 Generic Mapping Tools(GMT)绘制; 本文数据处理方面得到了中国地震局地质研究所王敏研究员的悉心指导; 陆态网络 运行维护中心全体人员及在西藏进行野外GPS台站建设的人员; 两位审稿人对本文的悉心指导, 其提出的建议 对本文质量提升有很大帮助, 在此一并感谢.

\section{参考文献}

1 Deng Q D, Zhang P Z, Ran Y K, et al. Basic characteristics of active tectonics of China. Sci China Ser D-Earth Sci, 2003, 46: 356-372 [邓 起东, 张培震, 冉勇康, 等. 中国活动构造基本特征. 中国科学 D辑：地球科学, 2002, 12: 1020-1030, 1057]

2 Molnar P, Tapponnier P. Cenoaoic tectonics of Aisa: Effects of a continental collision. Science, 1975, 189: 419-426

3 Tapponnier P, Molnar P. Active faulting and tectonics in China. J Geophys Res, 1977, 82: 2905-2930

4 Deng Q D. Kinematic features and slip rates of Late Quaternary active faulting of Qinghai-Xizang (Tibet) Plateau and kinematic characteristics of the plateau and secondary blocks within it (in Chinese). In: Himalayan Geology International Symposium Abstracts. Chengdu, China: Himalayan Geology International Symposium Organizing Committee, 1984. 119-122 [邓起东. 青藏高原活动断裂晚第四纪的运 动性质和错动速率兼论青藏高原和内部次级块体的运动学特征. 见: 喜马拉雅地质科学国际讨论会论文摘要. 成都: 喜马拉雅地 质科学国际讨论会组织委员会. 1984. 119-122]

5 McCaffrey R, Nabelek J. Role of oblique convergence in the active deformation of the Himalayas and southern Tibet Plateau. Geology, 1998, 26: 691-694

6 Wang Q, Zhang P Z, Niu Z J, et al. Present-day crustal movement and tectonic deformation in China continental. Sci China Ser D-Earth Sci, 2002, 45: 865-874 [王琪, 张培震, 牛之俊, 等. 中国大陆现今地壳运动和构造变形. 中国科学 D辑：地球科学, 2001, 31: 529-536]

7 Zhang P Z, Wang Q, Ma Z J. GPS velocity field and active crustal blocks of contemporary tectonic deformation in China continental (in Chinese). Earth Sci Front, 2002, 9: 430-438 [张培震, 王琪, 马宗晋. 中国大陆现今构造运动的GPS速度场与活动地块. 地学前缘, 2002, 9: 430-438]

8 Lave J, Avouac J P. Active folding of fluvial terraces across the Siwaliks Hills, Himalayas of central Nepal. J Geophys Res, 2000, 105: 5735-5770

9 Nakata T. Active faults of the Himalaya of India and Nepal. Geol Soc Am Spec Pap, 1989, 232: 243-264

10 Avouac J P. Mountain building: From earthquakes to geological deformation. In: Dynamic Processes in Extensional and Compressional Settings: Treatise on Geophysics, 2007, 6: 377-439

11 Bilham R, Gaur V K, Molnar P. Himalayan seismic hazard. Science, 2001, 293: 1442-1444

12 Ader T, Avouac J, Liu-Zeng J, et al. Convergence rate across the Nepal Himalaya and interseismic coupling on the Main Himalayan Thrust: Implications for seismic hazard. J Geophys Res, 2012, 117: B04403, doi: 10.1029/2011JB009071

13 Tapponnier P, Xu Z Q, Roger F, et al. Geology-oblique stepwise rise and growth of the Tibet Plateau. Science, 2001, 294: 1671-1677

14 Avouac J P, Meng L, Wei S, et al. Lower edge of locked Main Himalayan Thrust unzipped by the 2015 Gorkha earthquake. Nat Geosci, 2015, 8: 708-713

15 Zhang Y, Xu L S, Chen Y T. Rupture process of the 2015 Nepal $M_{\mathrm{w}} 7.9$ earthquake: Fast inversion and preliminary joint inversion (in Chinese). Chin J Geophys, 2015, 58: 1804-1811 [张勇, 许力生, 陈运泰. 2015年尼泊尔 $M_{\mathrm{w}} 7.9$ 地震破裂过程: 快速反演与初步联合反 演. 地球物理学报, 2015, 5: 1804-1811]

16 Pritchard M E, Norabuena E O, Ji C, et al. Geodetic, teleseismic, and strong motion constraints on slip from recent southern Peru subduction zone earthquakes. J Geophys Res, 2007, 112: 1-4

17 Galetzka J, Melgar D, Genrich J, et al. Slip pulse and resonance of Kathmandu basin during the $2015 M_{\mathrm{w}} 7.8$ Gorkha earthquake, Nepal. Science, 2015, 349: 1091-1095

18 Herring T A, King R W, McClusky S C. GAMIT Reference Manual: GPS Analysis at MIT. Release 10.4. Department of Earth, Atmospheric, and Planetary Sciences, Massachusetts Institute of Technology. 2010

19 Herring T A, King R W, King R W. GLOBK Reference Manual: Global Kalman filter VLBI and GPS analysis program. Release 10.4. Department of Earth, Atmospheric, and Planetary Sciences, Massachusetts Institute of Technology. 2010

20 Lagler K, Schindelegger M, Böhm J. GPT2: Empirical slant delay model for radio space geodetic techniques. Geophys Res Lett, 2013, 40: 1069-1073

21 Boehm J, Niell A, Tregoning P, et al. Global Mapping Function (GMF): A new empirical mapping function based on numerical weather model data. Geophys Res Lett, 2006, 33: L07304, doi: 10.1029/2005GL025546 
22 Choi K, Bilich A, Larson K M, et al. Modified sidereal filtering: Implication for high-rate GPS positioning. Geophys Res Lett, 2004, 31: L24610, doi: 10.1029/2004GL021621

23 Wdowinski S, Bock Y, Zhang J, et al. Southern California permanent GPS Geodetic Array: Spatial filtering of daily positions for estimating coseismic and postseismic displacements induced by the 1992 Landers earthquake. J Geophys Res, 1997, 102: 18057-18070

24 Wang G Q, Boore D M, Tang G, et al. Comparisons of ground motions from colocated and closely spaced one-sample-per-second Global Position System and accelerograph recordings of the 2003 M6.5 San Simeon, California earthquake in the Parkfield Region. Bull Seismol Soc Am, 2007, 97: 76-90

25 Wang M, Li Q, Wang F, et al. Far-field co-seismic displacements associated with the 2011 Tohoku-Oki earthquake in Japan observed by Global Positioning System. Chin Sci Bull, 2011, 56: 2419-2424 [王敏, 李强，王凡，等. 全球定位系统测定的2011年日本宫城 $M_{\mathrm{w}} 9.0$ 级地震远场同震位移. 科学通报, 2011, 20: 1593-1596]

26 Shi C, Lou Y, Zhang H, et al. Seismic deformation of the $M_{\mathrm{w}} 8.0$ Wenchuan earthquake from high-rate GPS observations. Adv Space Res, 2010, 46: 228-235

27 Yin H T, Zhang P Z, Gan W J, et al. Near-field surface movement during the Wenchuan $M_{\mathrm{s}} 8.0$ earthquake measured by high-rate GPS. Chin Sci Bull, 2010, 55: 2529-2534 [殷海涛, 张培震, 甘卫军, 等. 高频GPS测定的汶川 $M_{\mathrm{s}} 8.0$ 级地震震时近场地表变形过程. 科学 通报, 2010,26: 2621-2626]

28 Larson K M, Bodin P, Gomberg J. Using 1-Hz GPS data to measure deformations caused by the Denali fault earthquake. Science, 2003, 300: $1421-1424$

29 Li X Z, Zhang G M. Earthquake activity in the Eurasian seismic zone and the earthquake in China mainland (in Chinese). Seismol Geol, 1994, 4: 300-304 [李献智, 张国民. 欧亚地震带地震活动和中国大陆地震. 地震地质, 1994, 4: 300-304]

30 Li X Z, Zhang G M, Lü M M. The relationship between the seismic activity of China, adjacent areas and China Continental Earthquakes (in Chinese). Earthquake, 1996, 103: 211-218 [李献智, 张国民, 吕梅梅. 中国大陆邻区的地震活动和中国大陆地震的关系. 地震, 1996, 103: 211-218]

31 Zhang G M, Li X Z, Geng L M. The seismic activity of the north boundary of India plate and the earthquake in China mainland (in Chinese). Earthquake, 1994, 3: 1-9 [张国民, 李献智, 耿鲁明. 印度板块北边界地震活动和中国大陆地震. 地震, 1994, 3: 1-9]

32 Chen X Z, Li Y E, Wang H X. On the relationship between seismic enhancement of the Eurasian seismic belt and the occurrences of $M \geqslant 7$ earthquakes in mainland China (in Chinese). Earthquake, 2014, 1: 34-40 [陈学忠, 李艳娥, 王恒信. 欧亚地震带地震活动增强与中国 大陆地区7级以上地震发生的关系分析. 地震, 2014, 1: 34-40]

33 Peng Y J, Zhou S Y, Zhuang J C, et al. An approach to detect the abnormal seismicity increase in Southwestern China triggered co-seismically by 2004 Sumatra $M_{\mathrm{w}} 9.2$ earthquake. Geophys J Int, 2012, 189: 1734-1740

34 Liu J, Ji C, Zhang J Y, et al. Tectonic setting and general features of co-seismic rupture of the 25 April, $2015 M_{\mathrm{w}} 7.8$ Gorkha, Nepal earthquake (in Chinese). Chin Sci Bull, 2015, 60: 2640-2655 [刘静, 纪晨, 张金玉, 等. 2015年4月 25 日尼泊尔 $M_{\mathrm{w}} 7.8$ 级地震的孕震构 造背景和特征. 科学通报, 2015, 60: 2640-2655]

35 Sheng S Z, Wan Y G, Jiang C S, et al. Preliminary study on the static stress triggering effects on China mainland with the 2015 Nepal $M_{\mathrm{s}} 8.1$ earthquake (in Chinese). Chin J Geophys, 2015, 58: 1834-1842 [盛书中, 万永革，蒋长胜，等. 2015年尼泊尔 $M_{\mathrm{s}} 8.1$ 强震对中国 大陆静态应力触发影响的初探. 地球物理学报, 2015, 58: 1834-1842]

36 Zhang B, Cheng H H, Shi Y L. Calculation of the co-seismic effect of $M_{\mathrm{s}} 8.1$ earthquake, April 25, 2015, Nepal (in Chinese). Chin J Geophys, 2015, 58: 1794-1803 [张贝, 程惠红, 石耀霖. 2015 年4月 25 日尼泊尔 $M_{\mathrm{s}} 8.1$ 大地震的同震效应. 地球物理学报, 2015 , 58: 1794-1803]

37 Patriat P, Achache J. India-Eurasia collision chronology has implications for crustal shortening and driving mechanism of plates. Nature, 1984, 311: 615-621 


\title{
Co-seismic displacement field associated with the 25 April, $2015 M_{\mathrm{w}} 7.8$ Nepal earthquake recorded by Global Positioning System
}

\author{
LI Yu ${ }^{1}$, LIU Jing ${ }^{2,3}$, LIANG Hong ${ }^{4}$, ZHANG Rui ${ }^{1}$, SHI HongBo ${ }^{1}$, WANG Peng ${ }^{2}$, LI JianYong ${ }^{1} \&$ \\ WANG Tan ${ }^{1}$ \\ ${ }^{1}$ National Earthquake Infrastructure Service, China Earthquake Administration, Beijing 100045, China; \\ ${ }^{2}$ Institute of Geology, State Key Laboratory of Earthquake Dynamics, China Earthquake Administration, Beijing 100029, China; \\ ${ }^{3}$ Institute of Tibetan Plateau Research, Chinese Academy of Sciences, Beijing 100101, China; \\ ${ }^{4}$ Meteorological Observation Centre, China Meteorological Administration, Beijing 100081, China
}

Continuous GPS observations in Nepal show that the April 25, $2015 M_{\mathrm{w}} 7.8$ earthquake caused a generally southward motion of the entire Nepal by as much as $1.88 \mathrm{~m}$ locally. The GPS data from CMONOC and JICA Projects in China and the network built by California Institute of Technology in Nepal are used to derive the co-seismic displacement field and to assess the dynamic response of the earthquake and its effect on crustal deformation in China. The results show that the co-seismic horizontal displacements associated with this earthquake are on the order of millimeters to centimeters in South Tibet, with the maximum of about $30 \mathrm{~mm}$ observed at the XZZF site, $220 \mathrm{~km}$ northeast of the epicenter. The co-seismic effect reaches as far as $1500 \mathrm{~km}$ away in the Qilian Shan region in northern Tibetan Plateau. Analysis of high-rate GPS data at $1 \mathrm{~Hz}$ show that sites within $1200 \mathrm{~km}$ of the epicenter record both the static, permanent offset, as well as the dynamic response of passing seismic waves, and directivity of co-seismic rupture. We compare the microseismic activity in China, event occurrence frequency before and after the earthquake. In contrast to the 2011 Tohoku-Oki earthquake, this earthquake did not cause a marked increase in the regional microseismic activity in China. Thus, the stress perturbation from the co-seismic process in most part of Tibetan Plateau, Sichuan-Yunnan region and the North-South seismic zone is relatively small, which is probably linked to its smaller magnitude.

Nepal $M_{\mathrm{w}} 7.8$ earthquake, co-seismic displacement, Himalayan orogenic belt, seismicity

doi: $10.1360 / \mathrm{N} 972015-00602$

\section{补充材料}

表 S1 GPS 观测到的尼泊尔 $M_{\mathrm{w}} 7.8$ 级地震的同震位移

本文以上补充材料见网络版 csb.scichina.com. 补充材料为作者提供的原始数据, 作者对其学术质量和内容负责. 